\title{
IS THE ŠUMAVA NATIONAL PARK CHANGING INTO A DESERT? A MINI-REVIEW
}

\author{
KAROLÍNA BÍLÁ ${ }^{1, *}$ and PAVEL KINDLMANN ${ }^{1,2}$ \\ ${ }^{1}$ Department of Biodiversity Research, Global Change Research Institute CAS, Bělidla 986/4a, 60300 Brno, Czech Republic \\ ${ }^{2}$ Institute of Environmental Studies, Charles University, Benátská 2, 12801 Prague 2, Czech Republic \\ * Corresponding author: bila.k@czechglobe.cz
}

\section{ABSTRACT}

The provoking title briefly represents the opinion of a number of politicians and lobbyists. The majority of biologists, however, do not agree with this statement and present several arguments for why such a change will not occur. We attempt to elucidate the current and future situation in the Šumava NP based on available data. We also compare the situation in the Šumava NP with that in the whole of the Czech Republic, where the situation is similar or even worse. The devastated spruce forests are regenerating from young seedlings, biodiversity is increasing and the national park is not threatened by drought any more than the surrounding landscape. Here we dismiss the alarming messages about a desert in the Šumava NP, as the opposite is true, with the drought level there lower than in the rest of the Czech Republic

Keywords: climate change; Czech Republic, drought; forest regeneration; mountains; Šumava

\section{Introduction}

During the last few decades climate change has been a major topic of study and its predicted effects on nature and society are being widely discussed. These changes are natural and occurred in the past; however, human activity has greatly speeded up this process. According to Intergovernmental Panel on Climate Change (IPCC 2018), human-induced warming has reached approximately $1{ }^{\circ} \mathrm{C}$ above pre-industrial levels and is increasing at $0.2{ }^{\circ} \mathrm{C}$ per decade.

A number of studies already indicate that air temperatures are increasing and precipitation patterns are changing and causing droughts, floods or decreases in snow cover around the world (Boer et al. 2000; Sillmann et al. 2013; IPCC 2018; Pasqui and Di Giuseppe 2019). However, the effects of climate change are not uniform and paradoxical as wet areas are becoming wetter, dry drier, high mountains are losing snow cover, glaciers are melting and sea level increasing. These facts encourage research into the effect fluctuations in weather on builtup areas, cultural landscapes and the remaining islands of untouched nature.

We focused on the situation in the Sumava National Park (NP), in the Czech Republic (CZ), where an extensive drought associated with annual precipitation of $500 \mathrm{~mm}$ was recorded in 2015. This low level of rainfall continued for two years and resulted in a low moisture balance, dry soils and a deficit of ground water (Boer et al. 2000; Bečka and Beudert 2016; Bílá 2016). This weather was favourable for the bark beetles infesting the spruce forests within the national park, which resulted many trees dying and stimulated heated debates about the proper management of the trees killed by the bark beetles (Hais and Kučera 2008; Pokorný and Hesslerová 2011; Kindlmann et al. 2012). In opposition to the scientific findings, it was argued the drought was caused by the bark beetle outbreak and death of the trees (Kunšteková 2019; Pokorný 2019). This mini-review attempts to resolve this debate.

\section{Situation in the Šumava NP}

\section{National park becoming a desert}

This statement is probably based on remote sensing data of the surface temperature measured by satellites or thermal cameras on hot summer days. These results do not take into account changes in habitats over time. However, it is important to consider not only the temperatures recorded, but also the structure of the vegetation, its exposure to sunshine and the number of trees per unit area (Kindlmann et al. 2012; Bílá 2018). Bečka and Beudert (2016) report an increase in summer air temperature of about $2^{\circ} \mathrm{C}$ since 1978 in the Šmava NP, which is less than the temperature increase due to warming, presented in the IPCC report.

There was also a relatively low decrease in air humidity $(4 \%)$ in the core zones of the national park. Even in "dead" forest after bark beetle attacks, higher amounts of precipitation were recorded than in the green forests. This might be due to more of the rain reaching the soil under dead trees than under live trees, where much of the rain falls on the leaves and subsequently evaporates (Hais and Pokorný 2004; Adams 2012; Lamačová et al. 2018; Kopáček et al. 2019). Similar measurements were recorded in the Krušné Mts. and Jizerské Mts. (CZ), which were affected by acidic rain in 80 s in the $20^{\text {th }}$ century.

Is the Sumava NP really the most threatened area in the Czech Republic because of the decrease in water level associated with bark beetle outbreaks? Fig. 1 shows the drought situation within the CZ in 2018 and depicts drought threats in a central part of the CZ but definitely not in the south-western border area, where the Sumava 


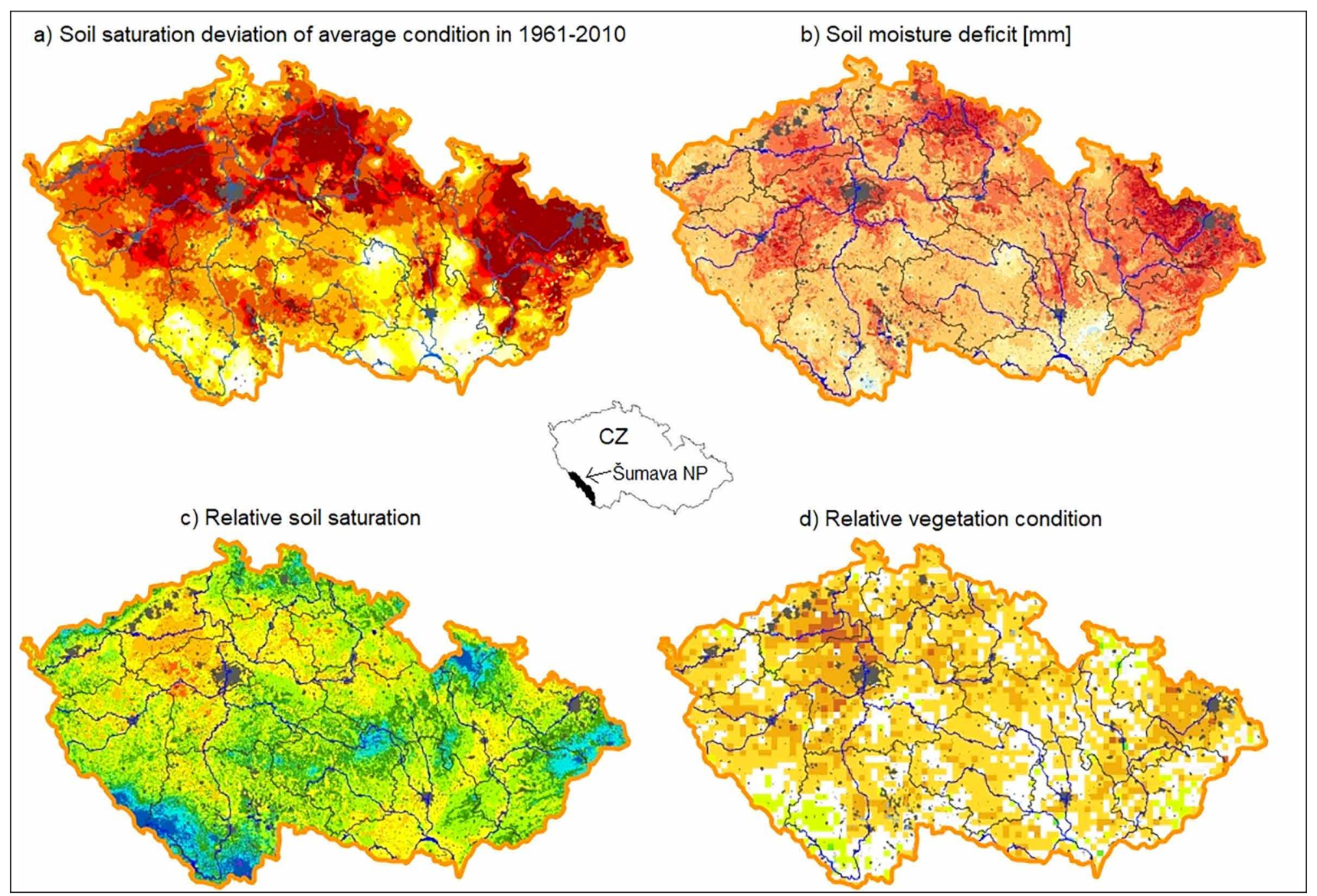

Fig. 1 Map showing the incidence of particular factors associated with drought in the Czech Republic in relation with the reference period 1961-2010 in July 2018 (https://www.intersucho.cz).

NP is located. When we compare soil water content and its saturation in the different mountain and highland areas of the CZ, we obtain very similar results: the Sumava $\mathrm{NP}$ is the best of the compared regions in terms of the absolute soil water content (Fig. 2).

\section{End of green forests}

Nature conservation is important in western society. It might be seen, however, as of little importance in view of the changes that have occurred naturally over time. The Šumava NP is a good example, as when its spruce forests mature, the old trees are prone to die for several reasons. Bark beetle outbreaks rapidly kill the mature trees and from an aesthetic point of view, Šumava loses its highly valued old forests that have been present for several human generations. It can be viewed as a tragedy or a natural cyclical event followed by regeneration, during which seedlings grow and develop into a young forest (Fig. 3). Disturbance followed by succession has occurred in the south-western border area of the Czech Republic over a very long period of time. Major changes in the characteristics of this forest are recorded in the years 1620, 1690, 1720, 1740, 1780, 1820, 1870 and 1920. Smaller changes in which at least $10 \%$ of the trees died were recorded in 41 years and more than $50 \%$ in 174 years. The greatest incidences of dying trees occurred at the beginning of the 19th century and recently, both of which can be attributed to the trees being mature and being more prone to being severely damaged by windstorms or killed by bark beetles (Hošek 1981; Kindlmann et al. 2012; Simanov 2014; Kjučukov et al. 2019).

This is also important for biodiversity, which tends to be higher in environments subject to some disturbance (Seidl et al. 2011; Kindlmann and Křenová 2016).

\section{Winners and losers in the forest structure}

The Šumava NP is protected because of the extensive forests growing on the mountains and their foothills along its south-western border. Over the last 8,000 years, spruce has been present at localities above $1,100 \mathrm{~m}$ a.s.l. and fir-beech forest and beech forests at lower altitudes. This vegetation was artificially modified, starting in the 18 th of century, which resulted in the area under beech declining because it was used in the glass industry or because beech was replaced by spruce, which is more profitable. Original and untouched spruce forests occur on the highest summits, because it is difficult to $\log$ these areas (Šantrůčková et al. 2010; Kjučukov et al. 2019). 


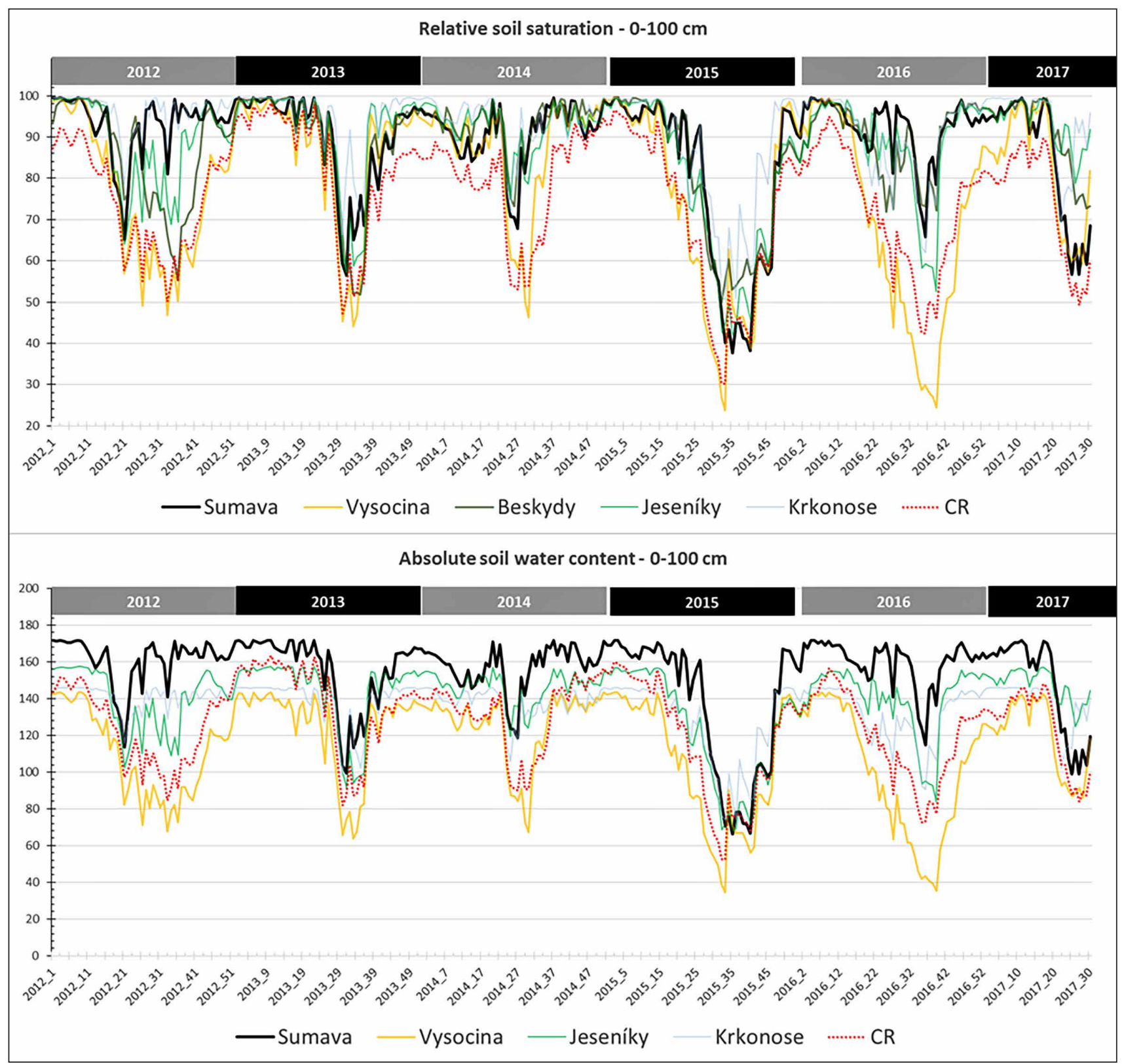

Fig. 2 Relative soil saturation and absolute soil water content at a depth of 0-100 cm in years 2012-2017 recorded in in the different mountain and highland areas in the Czech Republic.

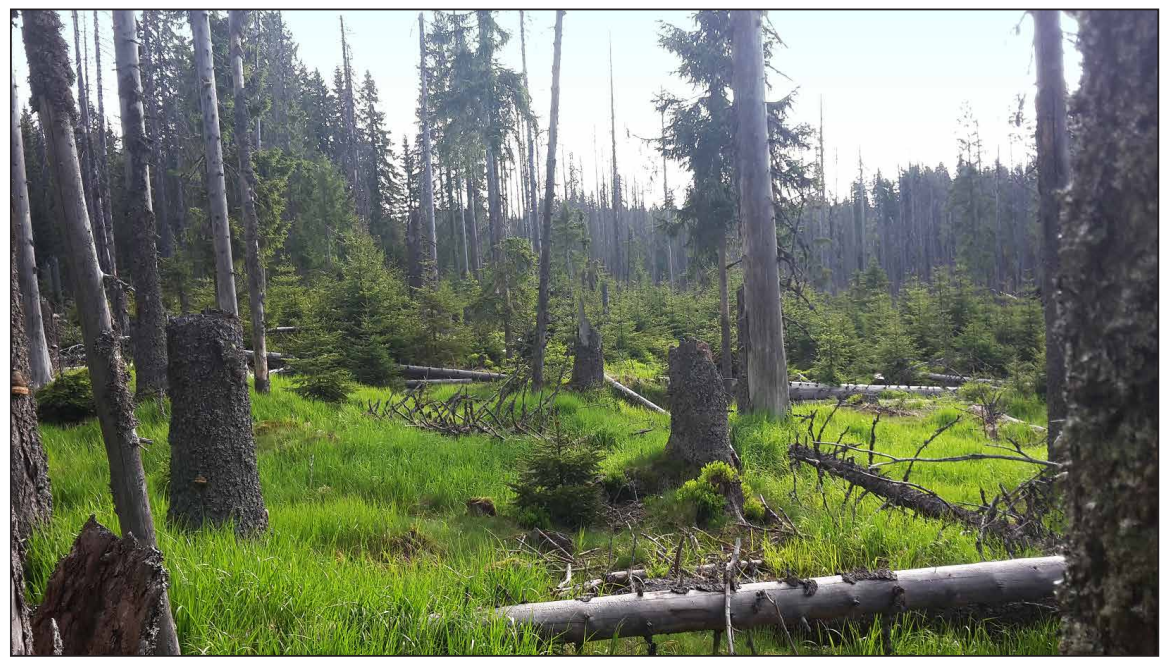

Fig. 3 Growth of spruce seedlings in an area of forest killed by bark beetles. 


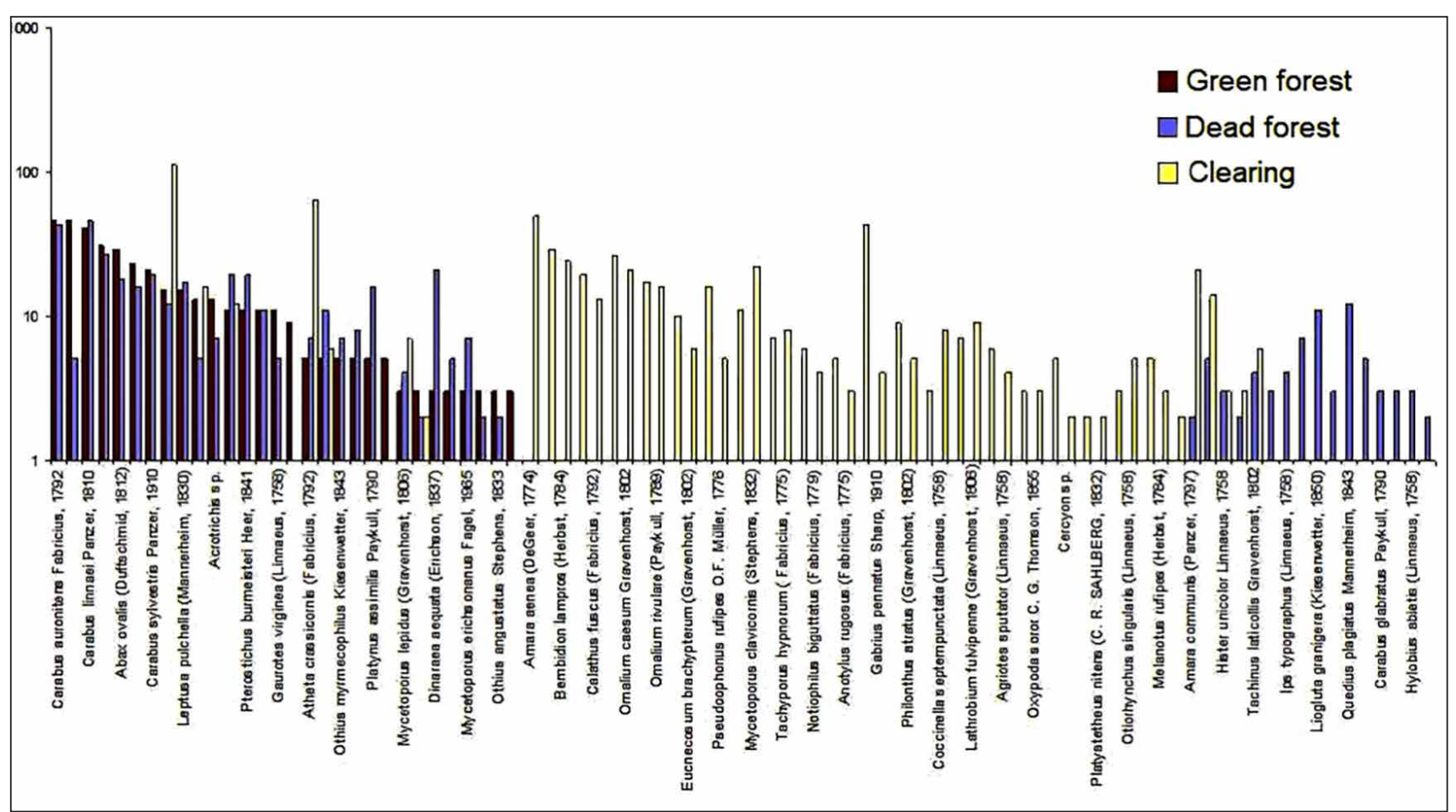

Fig. 4 Comparison of the diversity of carabids in green forest, dead forest and clearings.

With the predicted increase in temperature, it is expected that broadleaf trees will eventually colonize the higher altitudes; however, this currently is not occurring, as there are only spruce seedlings and closed canopy spruce in most of the core area of the Šumava NP. The spruce seedlings grow in clusters in suitable microhabitats, such as those associated with prostrate tree trunks or stumps in the vicinity of dead trees. Natural spruce forest regeneration is characterized by a spatial mosaic of microhabitats. Even dead trees serve as a refuge for many animals, such as carabids: species characteristic for spruce mountain forests remain present even after a bark beetle outbreak, but disappear in clearings - most likely due to change of microclimate there (Fig. 4). With the predicted increase in global temperature, the species composition of ground beetles is likely to change. There will be winners and losers in these forests, some species will profit from the temperature increase and some will be affected negatively (Müller-Kroehling et al. 2014).

\section{Conclusion}

The last few years were extremely dry and affected the Šumava NP. Spruce forests there suffered attack by bark beetles that can have more than one generation a year and can spread very fast. Similar situations were recorded in other mountains and highlands in the Czech Republic. Bark beetle outbreaks also occurred in the north of Moravia and in the Bohemian-Moravian Highlands. Suggesting that the core zones in the NP, where the valu- able ecosystems are conserved, are the reason for bark beetle outbreak is misleading.

Although the dead trees in these core zones might be considered by most of people to be unsightly, they are important for spruce forest regeneration (Schwarz 2013). Abiotic conditions at these sites are not so hot as to change the Šumava NP into a desert as claimed by Kunšteková (2019) and Pokorný (2019). Differences in the energy balance in dead and green forests is only a temporary phenomenon as the seedlings growing in the dead forest will quickly result in the regeneration of a green forest (Økland et al. 2015). In the case of the Šumava NP spruce forest, this proceeded very fast during the first decade after the bark beetle outbreak and was accompanied by an increase in relative air humidity (Kopáček et al. 2019).

A recent study by the Czech Hydrometeorological Institute confirms there have been no extreme changes in precipitation in the Sumava NP and surrounding foothills (Bílá et al. 2018). Changes probably will occur in terms of vegetation cover and drying out of soil but have not yet started (Fig. 1). On the contrary, the soil beneath dead prostrate tree trunks is damp and the trunk provides shade suitable for the establishment of mosses, which provide favourable conditions for the growth of spruce seedlings (Šantrůčková et al. 2010; Kindlmann et al. 2012; Bílá 2018). There is not the same growth of forest in the Šumava NP as before the bark beetle outbreak, but under current conditions, succession will result in a green forest made up of trees of different ages (Jonášová and Prach 2004). That is, the valuable ecosystems in the Šumava NP will not be replaced by a desert in the near future. 


\section{Acknowledgements}

This research was supported by the MSMT within the National Sustainability Program I (NPU I), grant number LO1415. We thank to Miroslav Trnka for providing us by Figure 2.

\section{REFERENCES}

Adams HD, Luce CH, Breshears DD, Allen CD, Weiler M, Hale VC, Smith AMS, Huxman TE (2012) Ecohydrological consequences of drought-and infestation-triggered tree die-off: insights and hypotheses. Ecohydrology 5: 145-159.

Bečka P, Beudert B (2016) Kůrovec a voda. Jak bezzásahovost ovlivňuje vodní režim na Šumavě. Šumava, Spring: 16-17, (in Czech).

Bílá K (2016) Are bark beetles responsible for droughts in the Šumava Mts.? Eur J Environ Sci 6: 108-113.

Bílá K (2018) Is measuring of temperature fluctuations following bark beetle infestation in differentially managed forests objective? Eur J Environ Sci 8: 124-130.

Bílá K, Hostýnek J, Kindlmann, P (2018) Comparison of precipitation and temperature regime in the Šumava National Park and in the surrounding foothills. Eur J Environ Sci 8: 131-138.

Boer G, Flato G, Ramsden D (2000) A transient climate change simulation with greenhouse gas and aerosol forcing: projected climate to the twenty-first century. Clim Dynam 16: 427-450.

Hais M, Kučera T (2008) Surface temperature change of spruce forest as a result of bark beetle attack: Remote sensing and GIS approach. Eur J Forest Res 127: 327-336.

Hais M, Pokorný J (2004) Changes in land cover temperature and humidity parameters resulting from spruce forests decay. Aktuality šumavského výzkumu II: 49-55, (in Czech).

Hošek E (1981) Studie o výskytu kalamit na území ČSR od roku 1900: Brandýs nad Labem: Lesprojekt 10-12: 8-86, (in Czech).

IPCC (2018) Summary for Policymakers. In: Global warming of $1.5^{\circ} \mathrm{C}$. An IPCC Special Report on the impacts of global warming of $1.5^{\circ} \mathrm{C}$ above pre-industrial levels and related global greenhouse gas emission pathways, in the context of strengthening the global response to the threat of climate change, sustainable development, and efforts to eradicate poverty. In: Masson-Delmotte V, Zhai P, Pörtner HO, Roberts D, Skea J, Shukla PR, Pirani A, Moufouma-Okia W, Péan C, Pidcock R, Connors S, Matthews JBR, Chen Y, Zhou X, Gomis MI, Lonnoy E, Maycock T, Tignor M, Waterfield T (eds) World Meteorological Organization, Geneva, Switzerland.

Jonášová M, Prach K (2004) Central-European mountain spruce forests: regeneration of tree species after a bark beetle outbreak. Ecol Eng 23: 15-27.
Kindlmann P, Křenová Z (2016) Biodiversity: Protect Czech park from development. Nature 531: 448.

Kindlmann P, Matějka K, Doležal P (2012) Lesy Šumavy, lýkožrout a ochrana přírody. Karolinum, Praha, (in Czech).

Kjučukov P, Hubený P, Čížková P, Čada V, Bače R, Matějka K, Hruška J, Zenáhlíková J, Hořejší M, Svoboda M (2019) Horské smrčiny národního parku Šumava ve faktech. Lesnická Práce 3: 20-23.

Kopáček J, Bače R, Hejzlar J, Kaňa J, Kučera T, Matějka K, Porcal P, Turek J (2019) Changes in microclimate and hydrology in an unmanaged mountain forest catchment after insect induced tree dieback. Sci Total Environ (submitted).

Kunšteková J (2019) Biolog Pokorný: Kůrovec je obrovský průšvih. Pokud chceme vyřešit sucho, musíme na Šumavu vrátit vzrostlý les. Prima, 14. 7. 2019, https://prima.iprima.cz/zpravodajstvi /biolog-pokorny-kurovec-je-obrovsky-prusvih-pokud-ch -ceme-vyresit-sucho-musime-na-sumavu.

Lamačová A, Hruška J, Trnka M, Štěpánek P, Zahradníček P, Meitner J, Farda A (2018) Modelling future hydrological pattern in a Bohemian Forest headwater catchment. Silva Gabreta 24: 47-67.

Müller-Kroehling S, Jantsch MC, Fischer HS, Fischer A (2014) Modelling the effects of global warming on the ground beetle (Coleoptera: Carabidae) fauna of beech forests in Bavaria, Germany. Eur J Entomol 111: 35-49.

Pasqui M, Di Giuseppe E (2019) Climate change, future warming, and adaptation in Europe. Anim Front 9: 6-11.

Økland B, Netherer S, Marini L (2015) The Eurasian spruce bark beetle: The role of climate. In: Björkman C, Niemelä P (eds) Climate Change and Insect Pests. CABI Climate Change Series, UK, pp 202-219.

Pokorný J (2019) Už toho šílenství nechte. Echo 24, 2. 9. 2019, http://www.silvarium.cz/zpravy-z-oboru-lesnictvi-a-drevarstvi /uz-toho-silenstvi-nechte-tydenik-echo.

Pokorný J, Hesslerová P (2011) Odlesňování a klima. Klimatické změny v Mau Forest v západní Keni. Vesmír 90: 573-578, (in Czech).

Šantrůčková H, Vrba J et al. (2010) Co vyprávějí šumavské smrčiny: průvodce lesními ekosystémy Šumavy. Správa Národního parku a Chráněné krajinné oblasti Šumava, (in Czech).

Schwarz J (2013) Clearing forest may transform local and global climate. Sci Am: March 4.

Seidl R, Schelhass MJ, Lexer MJ (2011) Unraveling the drivers of intensifying forest disturbance regimes in Europe. Global Change Biol 17: 2842-2852.

Sillmann, J, Kharin VV, Zhang X, Zwiers FW, Bronaugh D (2013) Climate extremes indices in the CMIP5 multimodel ensemble: part 1. Model evaluation in the present climate. J Geophys Res Atmos 118: 1716-1733.

Simanov V (2014) Kalamity v historii a současnosti. Lesnická práce 93: 573-575, (in Czech). 